\title{
Carbon dynamics, potential and cost of carbon sequestration in double rice cropping system in semi-arid southern India
}

\author{
Krishna Chaitanya Anantha ${ }^{1 *}$, Shyam Prasad Majumder ${ }^{2}$, Dhaneshwar Padhan ${ }^{3}$, Shrikant \\ Badole $^{2}$, Ashim Datta ${ }^{4}$, Biswapati Mandal², Kiran Reddy Gade ${ }^{1}$
}

${ }^{1}$ Professor Jayashankar Telangana State Agricultural University, Jagtial, Telangana- 505529, India. ${ }^{2}$ Bidhan Chandra KrishiViswavidyalaya, Mohanpur, West Bengal-741252, India. Institute of Agricultural Science, Siksha O Anusandhan University, Bhubaneswar, Odisha-751003, India ${ }^{4}$ CAR-Central Soil Salinity Research Institute, Karnal-132 001, Haryana, India.*Corresponding author: krishnachaitanya@pjtsau.edu.in

\begin{abstract}
Studying the dynamics of soil organic carbon (SOC) is important for understanding the mechanistic pathways of $\mathrm{C}$ stabilization into different SOC pools. An attempt was, therefore, made to assess the impact of double rice cropping system with different levels of fertilizers and in combination with organics on $\mathrm{C}$ sequestration and its stabilization in an Inceptisol using a 14-year old experiment at Jagtial under semi-arid climate in India. Total organic carbon (TOC) allocated into different pools in order of very labile $>$ less labile $>$ non labile $>$ labile, constituting about 41.4, 20.6, 19.3 and 18.7\%, respectively. In comparison with control, system receiving farmyard manure (FYM-10 Mg ha-1 season $^{-1}$ ) alone showed greater C build up (40.5\%) followed by $100 \%$ NPK+FYM (120:60:40 kg N,P,K ha ${ }^{-1}+5 \mathrm{Mg} \mathrm{FYM} \mathrm{ha}^{-1}$ season $\left.^{-1}\right)(16.2 \%)$. In fact, a net depletion of carbon stock was observed with $50 \%$ NPK $\left(-1.2 \mathrm{Mg} \mathrm{ha}^{-1}\right)$ and control $\left(-1.8 \mathrm{Mg} \mathrm{ha}^{-1}\right)$ treatments. Only $28.9 \%$ of C applied through FYM was stabilized as SOC. A minimal input of $2.34 \mathrm{Mg} \mathrm{C}^{-1} \mathrm{y}^{-1}$ is needed to maintain SOC level. Treatments with organics showed a higher carbon management index, and microbial biomass and other labile pools of SOC. Results also indicated that $100 \%$ NPK + FYM could maintain yield sustainability with a lower cost of carbon sequestration.
\end{abstract}

Keywords: Rice, SOC pool, farmyard manure, C sequestration, stabilization, critical carbon input, cost of carbon sequestration. 


\section{Introduction}

Rice is one of the most important crops in the world and it contributes more than two thirds of the energy intake of population of South and South East Asia including India (Timsina et al., 2010). About 45.5 million hectares of land in India is covered with rice producing 99.2 MT of grains, which contributes about $22.1 \%$ of world production (AIREA, 2008-09). Monoculture of rice using high yielding varieties and only inorganic fertilizers have been proved to stagnate rice productivity (Ladha et al., 2003), and the system is accredited with reducing fertility, nutrient supplying capacity and overall health of soils. In fact, results from long-term fertilizer experiments conducted throughout the world have revealed that application of only inorganic fertilizer to such rice-based system has damaged almost all good soil attributes for crop production including physical, chemical and biological properties (Basak et al., 2016). Maintaining the sustainability of such a production system is the need of the hour to achieve food security.

Organic carbon (OC) is the panacea for sustaining soil health. However, it is a major challenge to maintain or improve low-level stock of OC in soils of arid and semi-arid regions (Srinivasarao et al., 2012a, 2014). The problem is aggravated due to heavy soil-mining practices with little or no crop residues incorporated back into the soil, excessive tillage, ubiquitous imbalance in fertilizer use and severe unavoidable soil degradation by erosion and other obvious processes ( $\mathrm{Lal}$, 2009). Lal (2011) quantified that increasing the SOC stock by unit $\mathrm{MgC} \mathrm{ha}{ }^{-1} \mathrm{y}^{-1}$ in the root zone is supposed to increase annual food production in developing countries by 2432 million tons of food grains and 610 million tons of roots and tubers. Quantifying the pools of organic carbon in soil under different management practices is needed for improving quality and sustainability of the soils (Tian et al., 2015; Bharali et al., 2017). Organic carbon concentration determined by Walkley and Black (1934) and Nelson and Sommers (1982) methods may not be enough to assess the effect of management practices on the quality of a system to maintain soil sustainability (Chan et al., 2001). There are a few parameters of OC in soils including those of different pools. Computing relationships among those parameters viz., sensitivity index, carbon management index, critical $\mathrm{C}$ input and carbon pools with crop productivity will be useful in formulating better management practices for facilitating carbon sequestration and maintaining sustainability of production system in long run. One of the easy way to achieve this is to study the changes in different fractions of carbon with different stabilities and turnover rates as a function of agricultural management practices.

Globally, most agro-ecosystems are experiencing increased nutrient inputs especially of anthropogenically derived nitrogen $(\mathrm{N})$, which are about $30-50 \%$ greater than that from natural sources and tenfold greater than 100 years ago (Zang et al., 2016). As most of the soils in India are deficient in $\mathrm{N}$, its enrichment could affect crop biomass as well as below ground processes. This includes microbial activity, decomposition of organic carbon and its allocation into different pools. With the aim to explain temperature sensitivity of microbial $\mathrm{C}$ decomposition in soil aggregates through the use of the thermodynamic parameter $\mathrm{Q}_{10}$, Muñoz et al. (2016) showed that decomposition in soils from rainy zones was more sensitive to temperature increase than that of soils from drier areas. Tian et al. (2016) elaborately and essentially tried to explain the effect of different biotic and abiotic factors on SOC in semiarid grassland and suggested to establish grassland to improve the potential of SOC sequestration. All these observations may help to explain the results of our 
present study on $\mathrm{C}$ dynamics under a regime of inorganic $\mathrm{N}$ in dried area.

Assessing the true value of SOC in monetary terms is impractical as it is equal to monetary equivalent of ecosystem services provisioned (Lal, 2014). The ecosystem services include increasing net primary productivity and agronomic yield in the context of food and nutritional security, improving plant available water capacity in the root zone, reducing water runoff and soil erosion, mitigating/adapting to climate change, denaturing pollutants and purifying water, and enhancing biodiversity. Assessing monetary value of these services is thus a major challenge (Costanza et al., 2014). Whereas, assessing the value of soil carbon sequestrated in monetary terms is practicable. As it depends on monetarily measurable factors like soil, crop management practices and land use. We made a modest attempt to evaluate the cost of $\mathrm{C}$ sequestration out of the present study, which could be used in trading of carbon in national and international markets, besides benefitting farming community.

Studies on the effect of long-term fertilization and cropping systems on $\mathrm{C}$ dynamics are well documented by many researchers in India, but these studies are limited to Indo-Gangetic Plains (Mandal et al., 2007; Majumder et al., 2007; 2008), eastern India (Ghosh et al., 2010), western India (Chaudhury et al., 2017) and to some extent in extra peninsular of north eastern region (Bharali et al., 2017). However, there is hardly any study on $\mathrm{C}$ dynamics, potential and cost of $\mathrm{C}$ sequestration in soils as influenced by long-term fertilization and cropping system in Deccan plateau or semi-arid region of southern India. Serious degradation in natural resources in the region demands rehabilitation measures tailoring crop and soil management practices for long-term sustainability of its agroecosystem (Srinivasarao et al., 2012b). Summarizing results of a number of studies, Lal (2004) concluded that improved fertility management can enhance the
SOC content at the rate of $0.05-0.15 \mathrm{Mg} \mathrm{ha}^{-1} \mathrm{y}^{-1}$. Again, Benbi and Brar (2009) observed that adoption of balanced fertilization influenced $\mathrm{C}$ sequestration in soils due to their effects on crop growth; while Pathak et al. (2011) reported, on an average, $C$ sequestration rate of $0.17 \%$ under NPK+FYM compared to NPK treatments. As a ready prescription, optimal level of SOC can be achieved and maintained through adoption of an appropriate crop rotation (Wright and Hons, 2005), Integrated Nutrient Management INM (Schuman et al., 2002; Mandal et al., 2007; Majumder et al., 2008), and conservation tillage (Lal, 2009). Relationship among the sensitivity index, carbon management index, critical $\mathrm{C}$ input and carbon pools with crop productivity will help in formulating better management practices thereby facilitating carbon sequestration and maintaining sustainability of the production system in long run. In the present study, an attempt has been made (i) to determine the impacts of long-term intensive double rice cultivation on SOC stock and its sequestration potential, (ii) to measure the effect of different levels of fertilizations on reallocation of organic carbon into different pools and (iii) to measure cost of carbon sequestration for attaining a higher crop yield sustainability, using a 14-year-old long-term fertility experiment in an Inceptisol located in a semi-arid region of southern India.

\section{Materials and Methods}

\subsection{Experimental site}

A long-term field experiment with rice-rice cropping system was established in 2000 at the experimental farm of the Regional Agricultural Research Station, Jagtial $\left(18^{\circ} 45^{\prime} \mathrm{N}, 78^{\circ} 45^{\prime}\right.$ E, $71 \mathrm{~m}$ above sea level), Telangana, India located in semi-arid eco-region. The experimental site receives an average annual rainfall of approximately $750-900 \mathrm{~mm}$ and experiences mean 
annual minimum and maximum temperatures of 20.0 and $33.6^{\circ} \mathrm{C}$, respectively. The soil was classified as Typic Ustochrept. The site had the soil moisture and temperature regimes of ustic and isohyperthermic, respectively, and the length of growing period (LGP) in between 90150 days in a year. Soils having $\mathrm{pH}$ of $7.1, \mathrm{EC}-0.47 \mathrm{dSm}^{-1}$ and contained 382,280 , and $338 \mathrm{~g} \mathrm{~kg}^{-1}$ of sand, silt, and clay, respectively. The initial surface soil $(0-15 \mathrm{~cm})$ of the experimental site had total organic $\mathrm{C}$ of $9.4 \mathrm{~g} \mathrm{~kg}^{-1}$, bulk density of $1.47 \mathrm{Mg} \mathrm{m}^{-3}$ and available $\mathrm{N}, \mathrm{P}$ and $\mathrm{K}$ were 107.6, 19.6 and $364 \mathrm{~kg} \mathrm{ha}^{-1}$, respectively.

\subsection{Treatments and Crop Management}

Two rice (Oryza sativa L.) crops (cv. JGL 3855) were grown in sequence annually during the experimental period (2000-2014). The experiment was laid out in randomized block design with the following treatments: (i) control (plots without NPK fertilizers and organics), (ii) 50\% NPK (60:30:20 $\mathrm{kg} \mathrm{ha}^{-1}$ ), (iii) 100\% NPK (120:60:40 $\mathrm{kg} \mathrm{ha}^{-1}$ ), (iv) 150\% NPK (180:90:60 $\left.\mathrm{kg} \mathrm{ha}^{-1}\right)$, (v) $100 \%$ NPK + FYM $\left(5 \mathrm{Mg} \mathrm{ha}^{-1}\right.$ season $\left.^{-1}\right)$, (vi) FYM, $10 \mathrm{Mg} \mathrm{ha}^{-1}$ season $^{-1}$ and (vi) Fallow [no crop cultivation since initiation of the experiment, but native vegetation (grasses, herbs etc.) allowed to grow without any inputs and dressed down annual leaving the biomass onto the plot] in three replications. Requisite amount of well-decomposed FYM was applied to the specified plots (size: $12 \mathrm{~m} \times 9 \mathrm{~m}$, as per the treatment structure) 7 days before (with the onset of monsoon) ploughing for winter rice using a power tiller for well mixing with the soil. The field were ploughed thoroughly and flooded 2-3 days before transplanting for puddling and levelling. Twenty five days old seedlings were transplanted at a spacing of $15 \mathrm{~cm} \times 15 \mathrm{~cm}$ with two seedlings per hill in the field plots during mid-August. Similarly, summer rice was transplanted in mid-January with 30- day old seedlings because of their slow growth during winter.

\subsection{Soil Sampling}

Three representative soil samples were collected 10 days after harvesting of winter rice in 2014 from each of the plots in each replication from 0 to 15,15 to 30 and 30 to $45 \mathrm{~cm}$ depths with a bucket auger and pooled together to make composite sample for each depth and replication. After hand crushing and passing through a $2.0-\mathrm{mm}$ sieve, the soil samples were stored at $4{ }^{\circ} \mathrm{C}$, and used fresh within $24 \mathrm{~h}$ for estimating soil microbial biomass $\mathrm{C}$. A portion of the field moist soil samples was air dried, passed through 0.5 $\mathrm{mm}$ sieve, and used for analysis of different pools of C. Bulk density was measured following the method as described by Blake and Hartge (1986), using triplicate samples collected from all three depths of each replication using a core sampler $(0.05 \mathrm{~m}$ in diameter, $0.08 \mathrm{~m}$ in length).

\subsection{Soil analysis}

Soil organic carbon (SOC) was determined by using wet combustion method as described by Walkley and Black (1934). Different fractions of SOC were estimated through a modified Walkley and Black method as described by Chan et al. (2001) and Mandal et al. (2008) using 5, 10 and $20 \mathrm{ml}$ of concentrated $\mathrm{H}_{2} \mathrm{SO}_{4}$ (which corresponded respectively to $12.0 \mathrm{~N}, 18.0 \mathrm{~N}$ and $24.0 \mathrm{~N}$ of $\mathrm{H}_{2} \mathrm{SO}_{4}$ ). The amount of SOC determined using 5, 10 and $20 \mathrm{ml}$ of concentrated $\mathrm{H}_{2} \mathrm{SO}_{4}$ when compared with TOC, allowed separation of TOC into the following four different fractions of decreasing oxidizability.

Very labile (VL or $\mathrm{C}_{\text {pool }}$ ): organic $\mathrm{C}$ oxidisable under $12.0 \mathrm{~N} \mathrm{H}_{2} \mathrm{SO}_{4}$

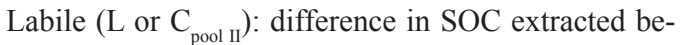
tween $18.0 \mathrm{~N}$ and $12.0 \mathrm{~N} \mathrm{H}_{2} \mathrm{SO}_{4}$. 
Less labile ( $\mathrm{LL}$ or $\mathrm{C}_{\text {pool III }}$ ): difference in SOC extracted between $24.0 \mathrm{~N}$ and $18.0 \mathrm{~N} \mathrm{H}_{2} \mathrm{SO}_{4}$.

Non labile ( $\mathrm{NL}$ or $\mathrm{C}_{\text {pool IV }}$ ): residual organic $\mathrm{C}$ after reaction with $24.0 \mathrm{~N} \mathrm{H}_{2} \mathrm{SO}_{4}$ when compared with the TOC.

Active soil carbon was determined by potassium permanganate $\left(0.02 \mathrm{M} \mathrm{KMnO}_{4}\right)$ oxidation method (Blair et al., 1995). It is very labile fraction of organic C sensitive to management practices. Particulate organic carbon was estimated by separating organic and mineral fractions of SOC sized between 53-200 microns and measuring by CHNS (Elementer Vario El Cube, Germany) analyser (Hassink, 1995). It varies from active soil carbon as it is often associated with the slow pool of organic C (Cambardella and Elliott, 1992). Microbial biomass carbon in the soil samples was estimated through chloroform fumigation and incubation method as outlined by Vance et al. (1987). Both fumigated and non-fumigated samples were extracted with $0.5 \mathrm{M} \mathrm{K}_{2} \mathrm{SO}_{4}$. The difference between $\mathrm{C}$ obtained from the fumigated and the non-fumigated samples was taken to represent the microbial C-flush and converted to microbial biomass carbon dividing C-flush with 0.41 (Voroney and Paul 1984).

Total carbon (TC) in the soil samples and organics were analyzed by the CHNS analyzer. Soil samples were also analyzed for soil inorganic carbon (calcium carbonate) by manometric method using Collin's calcimeter (Allison and Moodie, 1965). Total organic $\mathrm{C}$ content in soil was estimated by subtracting the amount of inorganic carbon from the total carbon. Organic $\mathrm{C}$ stock in soils was calculated by using following formula (Datta et al., 2015):

$\mathrm{C}$ stock in soil $=\mathrm{C}$ content $\times$ Bulk density $\times$ Depth

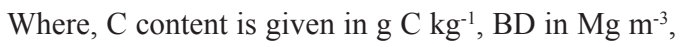
depth in $\mathrm{m}$ and $\mathrm{C}$ stock in $\mathrm{Mg} \mathrm{ha}^{-1}$.

Based on these analyses, the total amount of organic $\mathrm{C}$ applied to the soil through organic amendments was calculated on dry weight basis. Carbon budgeting for the studied systems was done as follows:

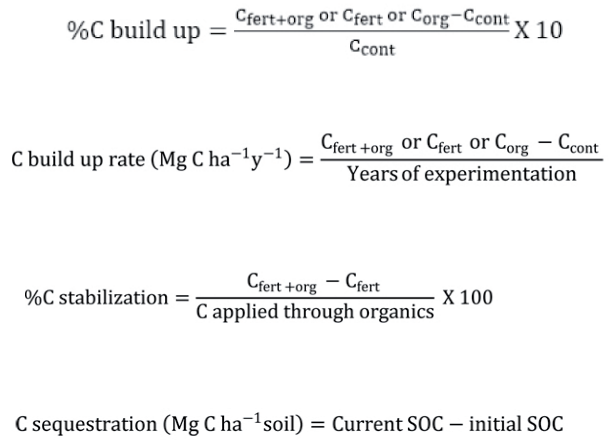

Sensitivity index:

\subsection{Carbon management index}

The carbon management index (CMI) was calculated using the mathematical procedures developed by Blair et al. (1995) as described below:

$$
\mathrm{CMI}=\mathrm{CPI} \times \mathrm{LI} \times 100
$$

Where, CPI is the carbon pool index and LI is the lability index. The CPI and the LI are calculated as follow:

Carbon pool index (CPI):

Total organic carbon in fertilized treatment Total organic carbon in control treatment 
Lability index (LI):

\section{Lability of carbon in fertilized treatment}

Lability of carbon in control treatment

Lability of carbon (L)

$\frac{\text { Coxidized by } \mathrm{KMnO}_{4}}{\mathrm{C} \text { unoxidized by } \mathrm{KMnO}_{4}}$

\subsection{Sustainable yield index}

The productivity of double rice cropping system was calculated through a sustainable yield index (SYI) using yield-data of 14 years. This was done to offset annual variations in the yield, and to highlight the performance of the treatments during the entire experimental period. The sustainable yield index is calculated using the following equation:

$$
S Y I=\frac{Y-\sigma}{Y m}
$$

where $\mathrm{Y}$ is the average yield. $\sigma$ is its estimated standard deviation, and $\mathrm{Ym}$ is the observed maximum yield in the experiment during the years of cultivation (Sharma et al., 2005).

\subsection{Cumulative Carbon Input}

The cumulative $\mathrm{C}$ input values for the studied cropping systems were computed using harvested yield data for the last 14 years (2000-2014). Empirical equations were used to estimate crop residue-derived $\mathrm{C}$ inputs. Stubble biomass and rhizodeposition $\mathrm{C}$ of rice, was assumed to be 2.5 and $15 \%$ of total above ground biomass at maturity and root biomass assumed as 19 and $14 \%$ of total above ground biomass for control and other fertilized treatments, respectively (Bronson et al., 1998). The extra C input through photosynthetic aquatic organism of rice was also ac- counted following Saito and Watanabe (1978). The estimated $\mathrm{C}$ concentrations of rice stubbles and root residues were 31.8 and $41.2 \%$, while mean $\mathrm{C}$ concentrations of FYM was $26.4 \%$, respectively.

\subsection{Economics of carbon sequestration}

If we consider the crop yield as complement of carbon sequestration, the cost of producing crops/ cost of cultivation will be the cost of carbon sequestration. The cost of rice crop cultivation per hectare under different treatments was calculated separately by taking into account the prices of various inputs like land preparation, seed, fertilizer, charges of human labour, fertilizer application, plant protection, harvesting and threshing. The cost and returns were calculated using current market prices of inputs and rice grain (minimum support price offered by the Government of In$\mathrm{dia}=1400 / 100 \mathrm{~kg}$ rice). Net return was calculated as the difference between gross income and total costs of inputs. Partial factor productivity (PFP) was calculated using the following equation:

PFP $=\frac{\text { Price of produce } ₹ \mathrm{ha}^{-1}}{\text { Price of N, } \mathrm{P} \text { and } \mathrm{K} \text { through fertilizer and manure ₹ ha- }}$

Cost of carbon sequestration:

$$
\frac{\text { Amount of carbon sequestrated over the years }\left(\mathrm{Mg} \mathrm{ha}^{-1}\right)}{\text { Cumulative cost of cultivation over the years }\left(₹ \mathrm{ha}^{-1}\right)}
$$

\subsection{Statistical analysis}

The data were analysed using randomized block design (RBD). Statistical analysis was performed by DOSbased SPSS version 17.0. The SPSS procedure was used for analysis of variance (ANOVA) to determine the statistical significance of treatments. The $5.0 \%$ probability level is regarded as statistically significant. 


\section{Results}

\subsection{Total organic carbon}

Intensive cultivation of double rice with recommended doses of fertilization (100\% NPK and $150 \%$ NPK) and $\mathrm{C}$ supplementation $(100 \% \mathrm{NPK}+\mathrm{FYM}$ and $100 \%$ FYM) caused an increase in TOC concentration in soil where as imbalanced fertilization $(50 \%$ NPK and control) decreased the same as compared to its (TOC) initial value and value with no cultivation fallow (Table 1). Carbon supplemented treatments like $100 \%$ $\mathrm{NPK}+\mathrm{FYM}$ and FYM maintained as much as 9.2 and $21.8 \%$ higher TOC, respectively over the $100 \%$ NPK. Irrespective of treatments, we found abrupt decline in SOC concentration along soil depth, with middle (15$30 \mathrm{~cm})$ and lower $(30-45 \mathrm{~cm})$ layers contained only 27.4 and $17.6 \%$ of total profile $(0-45 \mathrm{~cm})$ carbon content.

Table 1.Oxidisable and total organic carbon content $\left(\mathrm{g} \mathrm{kg}^{-1}\right)$ in soils at different depths under varied crop management practices

\begin{tabular}{l|cccc|cccc}
\hline \multirow{2}{*}{ Treatment } & \multicolumn{3}{|c|}{ Oxidizable organic carbon $\left(\mathrm{g} \mathrm{kg}^{-1}\right)$} & \multicolumn{3}{c}{ Total organic carbon $\left(\mathrm{g} \mathrm{kg} \mathrm{kg}^{-1}\right)$} \\
\cline { 2 - 9 } & $0-15 \mathrm{~cm}$ & $15-30 \mathrm{~cm}$ & $30-45 \mathrm{~cm}$ & Total & $0-15 \mathrm{~cm}$ & $15-30 \mathrm{~cm}$ & $30-45 \mathrm{~cm}$ & Total \\
\hline Control & $7.5 \pm 0.2^{\mathrm{d}}$ & $3.0 \pm 0.6^{\mathrm{c}}$ & $2.5 \pm 0.3^{\mathrm{c}}$ & $13.0 \pm 0.4^{\mathrm{d}}$ & $8.7 \pm 0.4^{\mathrm{d}}$ & $4.2 \pm 0.9^{\mathrm{a}}$ & $2.7 \pm 0.2^{\mathrm{c}}$ & $15.6 \pm 0.5^{\mathrm{d}}$ \\
\hline $50 \%$ NPK & $8.0 \pm 0.2^{\mathrm{cd}}$ & $3.4 \pm 0.2^{\mathrm{bc}}$ & $2.7 \pm 0.3^{\mathrm{bc}}$ & $14.1 \pm 0.1^{\mathrm{cd}}$ & $9.1 \pm 0.7^{\mathrm{cd}}$ & $5.1 \pm 0.8^{\mathrm{a}}$ & $3.4 \pm 0.4^{\mathrm{ab}}$ & $17.6 \pm 1.9^{\mathrm{cd}}$ \\
\hline $100 \%$ NPK & $8.7 \pm 0.3^{\mathrm{bc}}$ & $3.9 \pm 0.4^{\mathrm{abc}}$ & $3.0 \pm 0.2^{\mathrm{ab}}$ & $15.6 \pm 0.6^{\mathrm{bc}}$ & $10.0 \pm 0.8^{\mathrm{cd}}$ & $5.4 \pm 0.2^{\mathrm{a}}$ & $3.5 \pm 0.2^{\mathrm{ab}}$ & $18.9 \pm 0.8^{\mathrm{bc}}$ \\
\hline $150 \%$ NPK & $8.8 \pm 0.1^{\mathrm{b}}$ & $4.1 \pm 0.1^{\mathrm{abc}}$ & $2.8 \pm 0.1^{\mathrm{bc}}$ & $15.8 \pm 0.2^{\mathrm{bc}}$ & $10.2 \pm 0.2^{\mathrm{c}}$ & $5.6 \pm 0.2^{\mathrm{a}}$ & $3.6 \pm 0.2^{\mathrm{a}}$ & $19.5 \pm 0.2^{\mathrm{bc}}$ \\
\hline $100 \%$ NPK+FYM & $9.4 \pm 0.5^{\mathrm{b}}$ & $4.2 \pm 0.1^{\mathrm{ab}}$ & $3.4 \pm 0.1^{\mathrm{a}}$ & $17.1 \pm 0.7^{\mathrm{ab}}$ & $11.5 \pm 1.1^{\mathrm{b}}$ & $5.5 \pm 0.2^{\mathrm{a}}$ & $3.7 \pm 0.4^{\mathrm{a}}$ & $20.6 \pm 1.2^{\mathrm{ab}}$ \\
\hline FYM & $10.3 \pm 1.0^{\mathrm{a}}$ & $4.6 \pm 0.1^{\mathrm{a}}$ & $3.0 \pm 0.2^{\mathrm{ab}}$ & $17.9 \pm 1.2^{\mathrm{a}}$ & $13.9 \pm 0.9^{\mathrm{a}}$ & $5.5 \pm 0.2^{\mathrm{a}}$ & $3.5 \pm 0.3^{\mathrm{ab}}$ & $23.0 \pm 1.3^{\mathrm{a}}$ \\
\hline Fallow & $7.9 \pm 0.1^{\mathrm{cd}}$ & $3.7 \pm 1.3^{\mathrm{abc}}$ & $2.6 \pm 0.3^{\mathrm{c}}$ & $14.2 \pm 1.7^{\mathrm{cd}}$ & $10.0 \pm 0.3^{\mathrm{cd}}$ & $5.1 \pm 1.9^{\mathrm{a}}$ & $3.0 \pm 0.1^{\mathrm{cd}}$ & $18.1 \pm 2.3^{\mathrm{bcd}}$ \\
\hline
\end{tabular}

*values in the same column followed by different letters are significantly different at $\mathrm{P}<0.001$ according to Duncan's Multiple Range Test (DMRT) for separation of means, \pm indicates the standard deviation values.

\subsection{Organic C and its pools}

Oxidisable organic carbon concentration of surface soils $(0-15 \mathrm{~cm})$ was significantly increased with the application of inorganics, organics alone and combination of both, over the control treatment (Table 1). Cultivation over the years caused a net decrease in profile SOC under 50\% NPK and control treatments as compared to no cultivation fallow and the magni- tude of decline was 8.0 and $0.4 \%$, respectively. On the other hand, $100 \%$ NPK, $150 \%$ NPK, $100 \%$ $\mathrm{NPK}+\mathrm{FYM}$ and FYM treatments showed 10.0, $10.9,20.2$ and $25.8 \%$ increase in SOC, respectively over its value in fallow. Contents of SOC decreased abruptly in $15-30$ and $30-45 \mathrm{~cm}$ soil depths compared to the surface soil under all the treatments. The magnitude of decline between the lower depths (15-30 and 30-45 cm) was, however, non-significant. 
The magnitude of carbon pools extracted under a gradient of oxidizing conditions was as follows: $\mathrm{C}_{\mathrm{VL}}>$ $\mathrm{C}_{\mathrm{LL}}>\mathrm{C}_{\mathrm{NL}}>\mathrm{C}_{\mathrm{L}}$ constituting about 41.4, 20.6, 19.3 and $18.7 \%$, respectively, of the TOC (Table 2). However, the contribution of VL, L and LL pools to SOC was $51.2,23.1$ and $25.5 \%$, respectively. While active pool $\left(\mathrm{C}_{\mathrm{VL}}+\mathrm{C}_{\mathrm{L}}\right)$ constituted about $60.1 \%$, passive pool $\left(\mathrm{C}_{\mathrm{LL}}\right.$ $+\mathrm{C}_{\mathrm{NL}}$ ) represented $39.9 \%$ of the TOC.
Among the treatments, $100 \%$ NPK+FYM (44.4\%) maintained a proportionately higher amount of soil $\mathrm{C}$ in passive pools. With an increase in the dose of fertilization, on average, $\mathrm{C}$ allocation into passive pool was increased $(33.0,35.3,40.7 \%$ and $39.3 \%$ of TOC under control, $50 \%$ NPK, $100 \%$ NPK and $150 \%$ NPK treatments, respectively).

Table 2. Oxidisable organic carbon fractions (very labile, labile, less labile and nonlabile) in soils $\left(\mathrm{g} \mathrm{kg}^{-1}\right)$ at different layers $(\mathrm{cm})$ under the treatments studied

\begin{tabular}{|c|c|c|c|c|c|c|c|c|}
\hline Treatment & \multicolumn{4}{|c|}{ Very labile $\mathrm{C}$} & \multicolumn{4}{|c|}{ Labile C } \\
\hline & $0-15$ & $15-30$ & $30-45$ & Total & $0-15$ & $15-30$ & $30-45$ & Total \\
\hline Control & $3.6 \pm 0.5^{\mathrm{c}}$ & $1.4 \pm 0.3^{\mathrm{b}}$ & $1.3 \pm 0.2^{\mathrm{a}}$ & $6.3 \pm 0.4^{\mathrm{b}}$ & $2.4 \pm 0.3^{\mathrm{a}}$ & $1.0 \pm 0.2^{\mathrm{a}}$ & $0.8 \pm 0.4^{\mathrm{a}}$ & $4.2 \pm 0.6^{\mathrm{a}}$ \\
\hline $50 \%$ NPK & $4.6 \pm 0.3^{\mathrm{bc}}$ & $2.1 \pm 0.7^{\mathrm{ab}}$ & $1.5 \pm 0.1^{\mathrm{a}}$ & $8.1 \pm 0.9^{\mathrm{a}}$ & $1.7 \pm 0.4^{\mathrm{ab}}$ & $0.9 \pm 0.5^{\mathrm{a}}$ & $0.7 \pm 0.2^{\mathrm{a}}$ & $3.3 \pm 0.7^{\mathrm{a}}$ \\
\hline $100 \%$ NPK & $4.4 \pm 0.3^{\mathrm{bc}}$ & $2.3 \pm 0.2^{\mathrm{a}}$ & $1.4 \pm 0.5^{\mathrm{a}}$ & $8.0 \pm 0.7^{\mathrm{a}}$ & $1.8 \pm 0.4^{\mathrm{ab}}$ & $0.8 \pm 0.5^{\mathrm{a}}$ & $0.6 \pm 0.3^{\mathrm{a}}$ & $3.2 \pm 0.8^{\mathrm{a}}$ \\
\hline $150 \% \mathrm{NPK}$ & $5.0 \pm 0.2^{\mathrm{ab}}$ & $2.6 \pm 0.2^{\mathrm{a}}$ & $1.5 \pm 0.1^{\mathrm{a}}$ & $9.0 \pm 0.3^{\mathrm{a}}$ & $1.2 \pm 0.3^{\mathrm{b}}$ & $0.7 \pm 0.2^{\mathrm{a}}$ & $0.9 \pm 0.2^{\mathrm{a}}$ & $2.8 \pm 0.4^{\mathrm{a}}$ \\
\hline $100 \%$ NPK+FYM & $4.8 \pm 0.2^{\mathrm{ab}}$ & $2.0 \pm 0.2^{\mathrm{ab}}$ & $1.3 \pm 0.3^{\mathrm{a}}$ & $8.1 \pm 0.2^{\mathrm{a}}$ & $1.9 \pm 0.3^{\mathrm{ab}}$ & $0.7 \pm 0.2^{\mathrm{a}}$ & $0.7 \pm 0.3^{\mathrm{a}}$ & $3.4 \pm 0.2^{\mathrm{a}}$ \\
\hline FYM & $5.9 \pm 1.3^{\mathrm{a}}$ & $2.2 \pm 0.2^{\mathrm{a}}$ & $1.4 \pm 0.3^{\mathrm{a}}$ & $9.5 \pm 1.6^{\mathrm{a}}$ & $2.5 \pm 0.9^{\mathrm{a}}$ & $0.7 \pm 0.3^{\mathrm{a}}$ & $0.7 \pm 0.2^{\mathrm{a}}$ & $3.9 \pm 0.9^{\mathrm{a}}$ \\
\hline \multirow[t]{2}{*}{ Fallow } & $4.2 \pm 0.7^{\mathrm{bc}}$ & $1.5 \pm 0.5^{\mathrm{b}}$ & $0.7 \pm 0.3^{\mathrm{b}}$ & $6.3 \pm 0.8^{\mathrm{b}}$ & $2.2 \pm 1.0^{\mathrm{ab}}$ & $1.0 \pm 0.3^{\mathrm{a}}$ & $1.0 \pm 0.4^{\mathrm{a}}$ & $4.1 \pm 1.1^{\mathrm{a}}$ \\
\hline & \multicolumn{4}{|c|}{ Less labile $\mathrm{C}$} & \multicolumn{4}{|c|}{ Non labile $\mathrm{C}$} \\
\hline Control & $1.5 \pm 0.3^{\mathrm{c}}$ & $0.6 \pm 0.4^{\mathrm{c}}$ & $0.4 \pm 0.0^{\mathrm{c}}$ & $2.6 \pm 0.7^{d}$ & $1.2 \pm 0.5^{\mathrm{b}}$ & $1.2 \pm 0.3^{\mathrm{a}}$ & $0.2 \pm 0.2^{\mathrm{b}}$ & $2.6 \pm 0.5^{\mathrm{b}}$ \\
\hline $50 \%$ NPK & $1.8 \pm 0.1^{\mathrm{c}}$ & $0.4 \pm 0.1^{\mathrm{c}}$ & $0.5 \pm 0.2^{\mathrm{c}}$ & $2.7 \pm 0.1^{\mathrm{cd}}$ & $1.2 \pm 0.9^{\mathrm{b}}$ & $1.7 \pm 0.8^{\mathrm{a}}$ & $0.7 \pm 0.4^{\mathrm{ab}}$ & $3.5 \pm 1.8^{\mathrm{ab}}$ \\
\hline $100 \%$ NPK & $2.5 \pm 0.3^{\mathrm{ab}}$ & $0.8 \pm 0.1^{\mathrm{bc}}$ & $1.1 \pm 0.2^{\mathrm{ab}}$ & $4.4 \pm 0.1^{\mathrm{b}}$ & $1.3 \pm 0.6^{\mathrm{b}}$ & $1.5 \pm 0.6^{\mathrm{a}}$ & $0.5 \pm 0.2^{\mathrm{ab}}$ & $3.3 \pm 1.0^{\mathrm{ab}}$ \\
\hline $150 \%$ NPK & $2.6 \pm 0.2^{\mathrm{a}}$ & $0.9 \pm 0.1^{\mathrm{bc}}$ & $0.4 \pm 0.2^{\mathrm{c}}$ & $3.9 \pm 0.1^{\mathrm{b}}$ & $1.4 \pm 0.3^{\mathrm{b}}$ & $1.5 \pm 0.2^{\mathrm{a}}$ & $0.8 \pm 0.1^{\mathrm{a}}$ & $3.7 \pm 0.3^{\mathrm{ab}}$ \\
\hline $100 \%$ NPK+FYM & $2.7 \pm 0.6^{\mathrm{a}}$ & $1.5 \pm 0.2^{\mathrm{a}}$ & $1.4 \pm 0.1^{\mathrm{a}}$ & $5.6 \pm 0.7^{\mathrm{a}}$ & $2.0 \pm 0.8^{\mathrm{b}}$ & $1.3 \pm 0.1^{\mathrm{a}}$ & $0.3 \pm 0.3^{\mathrm{ab}}$ & $3.5 \pm 0.7^{\mathrm{ab}}$ \\
\hline FYM & $1.9 \pm 0.7^{\mathrm{bc}}$ & $1.7 \pm 0.2^{\mathrm{a}}$ & $1.0 \pm 0.2^{\mathrm{b}}$ & $4.5 \pm 0.7^{\mathrm{ab}}$ & $3.7 \pm 1.3^{\mathrm{a}}$ & $1.0 \pm 0.2^{\mathrm{a}}$ & $0.5 \pm 0.5^{\mathrm{ab}}$ & $5.1 \pm 1.9^{\mathrm{a}}$ \\
\hline Fallow & $1.5 \pm 0.3^{\mathrm{c}}$ & $1.3 \pm 0.7^{\mathrm{ab}}$ & $0.9 \pm 0.4^{\mathrm{b}}$ & $3.8 \pm 1.2^{\mathrm{bc}}$ & $2.1 \pm 0.2^{\mathrm{b}}$ & $1.4 \pm 0.7^{\mathrm{a}}$ & $0.4 \pm 0.2^{\mathrm{ab}}$ & $3.9 \pm 0.9^{\mathrm{ab}}$ \\
\hline
\end{tabular}

*values in the same column followed by different letters are significantly different at $\mathrm{P}<0.001$ according to Duncan's Multiple Range Test (DMRT) for separation of means, \pm indicates the standard deviation values.

\subsection{Labile C fractions}

Permanganate oxidizable carbon (POx-C) represents $3.7-4.6 \%$ of TOC (Table 3). Organics applied treatments showed significantly higher POx-C irrespective of soil depth. In fact, the POx-C is very sensitive to crop management practices as it varied significantly in all the treatments tested. Intensive double rice cultivation without any amendments (Control) significantly decreased the particulate organic carbon (POC) $\sim 1.8 \%$ when compared with no cultivation fallow in surface soil $(0-15 \mathrm{~cm})$, on the other hand increased over $0.6,9.0,13.2,23.4$ and $58.1 \%$ under $50 \%$ NPK, $100 \%$ NPK, $150 \%$ NPK, $100 \%$ $\mathrm{NPK}+\mathrm{FYM}$ and FYM treatments, respectively (Table 3).

Carbon associated with silt and clay fractions is stable in nature and it is increased with increasing carbon inputs into the soil. Organic amended treatments (FYM and 100\% NPK+FYM) showed significantly higher silt+clay associated $\mathrm{C}$ values over the fallow, control and $100 \%$ NPK only treatments in surface soils $(0-15 \mathrm{~cm})$. Different doses of fertilization had non-significant effect on it (Table 3). 
The $100 \% \mathrm{NPK}+\mathrm{FYM}$ and FYM treatments showed an increase in silt+clay $\mathrm{C}$ of 11.4 and $23.9 \%$ over the $100 \%$ NPK (Table 3 ).

Microbial biomass carbon (MBC) followed the same trend as oxidizable organic carbon. Higher amount of
MBC was observed in FYM treatment followed by $100 \%$ NPK+FYM, $150 \%$ NPK, 100\% NPK, fallow, $50 \%$ NPK and control (Table 3 ) indicating the additive effect of organics onto the MBC.

Table 3. Effect of crop management on permanganate oxidizable carbon (POx-C) particulate organic carbon (POC), microbial biomass carbon (MBC) and silt+clay associated carbon $\left(\mathrm{mg} \mathrm{kg}^{-1}\right)$ and sensitivity index of soil organic carbon and labile fractions of soil organic carbon in surface soil $(0-15 \mathrm{~cm})$.

\begin{tabular}{|c|c|c|c|c|c|c|c|c|c|}
\hline Treatment & POx-C & POC & $\mathrm{MBC}$ & Silt+clay C & \multicolumn{5}{|c|}{ Sensitivity index } \\
\hline Control & $335 \pm 22^{\mathrm{e}}$ & $1420 \pm 69^{\mathrm{e}}$ & $94 \pm 14^{\mathrm{e}}$ & $865 \pm 23^{d}$ & $\mathrm{OC}$ & POC & MBC & $\mathrm{S}+\mathrm{C}$ & POx-C \\
\hline $50 \% \mathrm{NPK}$ & $394 \pm 40^{\text {cd }}$ & $1680 \pm 12^{\mathrm{d}}$ & $123 \pm 16^{\mathrm{d}}$ & $875 \pm 68^{\mathrm{cd}}$ & $3.5^{\mathrm{c}}$ & $18.3^{\mathrm{c}}$ & $31.2^{\mathrm{b}}$ & $1.2^{\mathrm{b}}$ & $17.6^{\mathrm{c}}$ \\
\hline $100 \%$ NPK & $410 \pm 15^{\mathrm{cd}}$ & $1820 \pm 46^{\mathrm{c}}$ & $145 \pm 13^{\mathrm{bc}}$ & $920 \pm 46^{\mathrm{bcd}}$ & $12.6^{\mathrm{bc}}$ & $28.2^{\mathrm{c}}$ & $54.2^{\mathrm{b}}$ & $6.4^{\mathrm{b}}$ & $22.4^{\mathrm{c}}$ \\
\hline $150 \% \mathrm{NPK}$ & $442 \pm 13^{\mathrm{c}}$ & $1890 \pm 90^{c}$ & $155 \pm 6^{\mathrm{b}}$ & $980 \pm 17^{\text {bcd }}$ & $14.4^{\mathrm{bc}}$ & $33.1^{\mathrm{c}}$ & $64.8^{b}$ & $13.3^{\mathrm{b}}$ & $32.1^{\mathrm{bc}}$ \\
\hline $100 \% \mathrm{NPK}+\mathrm{FYM}$ & $523 \pm 17^{\mathrm{b}}$ & $2060 \pm 125^{\mathrm{b}}$ & $197 \pm 6^{\mathrm{a}}$ & $1025 \pm 71^{b}$ & $22.5^{\mathrm{ab}}$ & $45.1^{\mathrm{b}}$ & $109.3^{\mathrm{a}}$ & $18.5^{\mathrm{ab}}$ & $56.0^{\mathrm{b}}$ \\
\hline FYM & $646 \pm 57^{a}$ & $2640 \pm 104^{\mathrm{a}}$ & $216 \pm 14^{\mathrm{a}}$ & $1140 \pm 105^{\mathrm{a}}$ & $33.4^{\mathrm{a}}$ & $85.9^{\mathrm{a}}$ & $129.7^{\mathrm{a}}$ & $31.8^{\mathrm{a}}$ & $92.8^{\mathrm{a}}$ \\
\hline Fallow & $376 \pm 22^{\mathrm{de}}$ & $1670 \pm 17^{\mathrm{d}}$ & $126 \pm 12^{\mathrm{cd}}$ & $995 \pm 71^{\text {bc }}$ & $2.5^{\mathrm{c}}$ & $17.6^{\mathrm{c}}$ & $34.5^{\mathrm{b}}$ & $15.0^{\mathrm{ab}}$ & $12.4^{\mathrm{c}}$ \\
\hline
\end{tabular}

*values in the same column followed by different letters are significantly different at $p<0.001$ according to Duncan's Multiple Range Test (DMRT) for separation of means, \pm indicates the standard deviation values.

\subsection{C sequestration potential and stabilization}

Continuous cropping with no fertilizers (control) and insufficient fertilizers $(50 \% \mathrm{NPK})$ resulted in a net decrease in TOC by 9.2 and $5.1 \%$, respectively compared to its initial value in soil under rice-rice system. However, cultivation with balanced/sufficient mineral fertilizers and organics increased the TOC by $2.4,4.7,13.8,28.8$ and $6.8 \%$ under $100 \%$ NPK, $150 \%$ NPK, 100\% NPK+FYM, FYM and fallow treatments, respectively. All these resulted in a net gain or sequestration of SOC under different treatments as follows: FYM $\left(8.4 \mathrm{Mg} \mathrm{ha}^{-1}\right)>100 \%$ NPK+FYM $\left(3.4 \mathrm{Mg} \mathrm{ha}^{-1}\right)>$ fallow $\left(1.5 \mathrm{Mg} \mathrm{ha}^{-1}\right)>$ $150 \%$ NPK $\left(1.0 \mathrm{Mg} \mathrm{ha}^{-1}\right)>100 \%$ NPK $\left(0.6 \mathrm{Mg} \mathrm{ha}^{-1}\right)$ but a loss or depletion in 50\% NPK $\left(1.2 \mathrm{Mg} \mathrm{ha}^{-1}\right)$ and control (1.8 $\left.\mathrm{Mg} \mathrm{ha}^{-1}\right)$.

Carbon sequestration potential of the treatments also followed the same trend i.e. FYM $\left(0.60 \mathrm{Mg} \mathrm{ha}^{-1} \mathrm{y}^{-1}\right)$ $>100 \%$ NPK +FYM $\left(0.24 \mathrm{Mg} \mathrm{ha}^{-1} \mathrm{y}^{-1}\right)>$ fallow $(0.11$ $\left.\mathrm{Mg} \mathrm{ha}^{-1} \mathrm{y}^{-1}\right)>150 \% \operatorname{NPK}\left(0.07 \mathrm{Mg} \mathrm{ha}^{-1} \mathrm{y}^{-1}\right)>100 \%$ NPK (0.04 Mg ha-1 $\mathrm{y}^{-1}$ ) (Table 4). The amount and proportion of $\mathrm{C}$ applied in the form of FYM converted to SOC was computed (through equation 4) and it was observed that out of $13.72 \mathrm{Mg}$ of C contained in the $140 \mathrm{Mg}$ of FYM per ha, only $2.83 \mathrm{Mg}$ could be accounted for in the $100 \%$ NPK+FYM treatment. This indicated that $28.9 \%$ of the applied FYM-C was stabilized in the form of SOC allowing $71.1 \%$ to go out of the system. 
Table 4. Carbon sequestration in surface soil $(0-15 \mathrm{~cm})$ after 14 years of application of inorganic fertilizer and organic manures in a rice-rice cropping system.

\begin{tabular}{|c|c|c|c|c|c|c|c|}
\hline Treatment & $\begin{array}{c}\text { TOC } \\
\left(\mathrm{g} \mathrm{kg}^{-1}\right)\end{array}$ & $\begin{array}{l}\text { Bulk density } \\
\left(\mathrm{mg} \mathrm{m}^{-3}\right)\end{array}$ & $\begin{array}{l}\text { C Stock } \\
\left(\mathrm{mg} \mathrm{ha}^{-1}\right)\end{array}$ & $\begin{array}{c}\text { C sequestrated } \\
\left(\mathrm{mg} \mathrm{ha}^{-1}\right)\end{array}$ & $\begin{array}{c}\text { C sequestration } \\
\text { potential } \\
\left(\mathrm{mg} \mathrm{ha}^{-1} \mathrm{y}^{-1}\right)\end{array}$ & $\begin{array}{l}\text { \% build up } \\
\text { over control }\end{array}$ & $\begin{array}{c}\mathrm{C} \text { sequestrated } / \mathrm{kg} \\
\mathrm{N} \text { applied }\end{array}$ \\
\hline Initial & $9.4 \pm 0.0^{\text {cd }}$ & $1.47 \pm 0.0^{\mathrm{a}}$ & $20.7 \pm 0.0^{\text {cd }}$ & - & - & - & - \\
\hline Control & $8.7 \pm 0.4^{\mathrm{d}}$ & $1.45 \pm 0.04^{\mathrm{ab}}$ & $19.0 \pm 0.9^{\mathrm{d}}$ & $-1.7 \pm 1.3^{\mathrm{d}}$ & -0.12 & - & - \\
\hline $50 \%$ NPK & $9.1 \pm 0.7^{\text {cd }}$ & $1.43 \pm 0.02^{\mathrm{abc}}$ & $19.7 \pm 1.6^{\mathrm{d}}$ & $-1.0 \pm 1.5^{\mathrm{d}}$ & -0.07 & 3.7 & - \\
\hline $100 \%$ NPK & $10.0 \pm 0.8^{\mathrm{c}}$ & $1.42 \pm 0.02^{\mathrm{bc}}$ & $21.2 \pm 1.7^{\mathrm{cd}}$ & $0.5 \pm 1.8^{\mathrm{cd}}$ & 0.04 & 11.6 & 0.15 \\
\hline $150 \%$ NPK & $10.2 \pm 0.2^{\mathrm{c}}$ & $1.42 \pm 0.03^{\mathrm{bc}}$ & $21.7 \pm 0.4^{\mathrm{cd}}$ & $1.0 \pm 0.8^{\mathrm{cd}}$ & 0.07 & 14.3 & 0.20 \\
\hline $100 \%$ NPK+FYM & $11.5 \pm 1.1^{\mathrm{b}}$ & $1.40 \pm 0.02^{\mathrm{c}}$ & $24.0 \pm 2.3^{\mathrm{b}}$ & $3.3 \pm 2.5^{\mathrm{b}}$ & 0.24 & 26.3 & 0.25 \\
\hline FYM & $13.9 \pm 0.9^{\mathrm{a}}$ & $1.39 \pm 0.01^{\mathrm{c}}$ & $29.1 \pm 1.9^{c}$ & $8.4 \pm 2.0^{\mathrm{a}}$ & 0.60 & 53.0 & 0.21 \\
\hline Fallow & $10.0 \pm 0.3^{\mathrm{c}}$ & $1.48 \pm 0.04^{\mathrm{a}}$ & $22.2 \pm 0.7^{\mathrm{bc}}$ & $1.5 \pm 1.2^{\mathrm{bc}}$ & 0.11 & 16.8 & - \\
\hline
\end{tabular}

*values in the same column followed by different letters are significantly different at $\mathrm{P}<0.001$ according to Duncan's Multiple Range Test (DMRT) for separation of means, \pm indicates the standard deviation values.

\section{Discussion}

\subsection{Soil organic carbon and its fractions}

Cultivation over the years with control and 50\% NPK treatments caused a net decrease in both SOC $(8.5$ and $0.7 \%$ of the fallow, respectively) and TOC (13.8 and $2.8 \%$ of the fallow, respectively). Cultivation of double rice for 14 long years involved intensive tillage and puddling that destroyed soil structure, and subsequently affected distribution and stability of soil aggregates (Six et al., 2002) resulting in a decline in carbon content of soils. Our results are in line with Mandal et al. (2007) and Majumder et al. (2007, 2008) who reported similar magnitude of depletion in SOC (2-15\% of fallow) in subtropical India. In contrast, Lal (2004) reported, on average, $41 \%$ depletion in SOC in different regions of India including 57\% in Deccan Plateau. Lower magnitude of depletions in SOC observed in our study was primarily due to submergence of soils under rice-rice system for 8-9 months in a year. Higher SOC concentration in rice soils than in upland soil has been ascribed to favourable water regime during the rice season (Lal, 2004). Significant increase in SOC concentration from $<5.0$ $\mathrm{g} \mathrm{kg}^{-1}$ in 1973 to about $8.0 \mathrm{~g} \mathrm{~kg}^{-1}$ in 1994 in soils under rice with integrated nutrient management was also reported (Swarup, 1998). Another possible reason for lower depletion might be due to lower inherent carbon concentration of the experimental soil. However, sole application of FYM and in combination with $100 \%$ NPK significantly increased carbon content in soils. This was simply due to an increased biomass of crops (root biomass and root exudates) with complementary effect of organic and inorganic fertilizers. A similar build up of SOC due to cropping with combined application of fertilizer and FYM was reported by Majumder et al. (2008), and Chaudhary et al. (2017), with sole FYM by Srinivasarao et al. (2012b).

Treatments with external application of FYM showed a higher amount of POC than those with NPK. Chaudhary et al. (2017) also reported a higher POC in FYM treated soils, and explained that it originated from recalcitrant litter (Puget and Drinkwater, 2001), and root and microbial biomass debris (Purakayastha et al., 2008). Greater C concentrations in POC than silt+clay fraction (Table 3 ) indicated that carbon from crop residue and manure are more likely to accumulate in coarse size and light density fractions rather than in fine size. Results of lack of substantial accumulations of uncomplexed organic matter or lower amount of carbon in silt+clay fractions indicated that the mineral associated pool has not yet reached the (C) saturation (Feng et al., 2014). This assertion was 
supported by the observations that silt+clay fractions did not exhibit an asymptotic relationship with $\mathrm{C}$ inputs (Figure 1). The results thus indicated that silt+clay fractions still have a substantial $\mathrm{C}$ saturation deficit, and could stabilize additional amounts of $\mathrm{C}$ inputs. The $\mathrm{C}$ saturation deficit of soils of the present study after cultivation of double rice for 14 years with organics may be due to the shorter duration of the experiment and application of a limited/ insufficient amount of organics as well as a lower initial SOC concentration of the soils (Stewart et al., 2007; Feng et al., 2014).

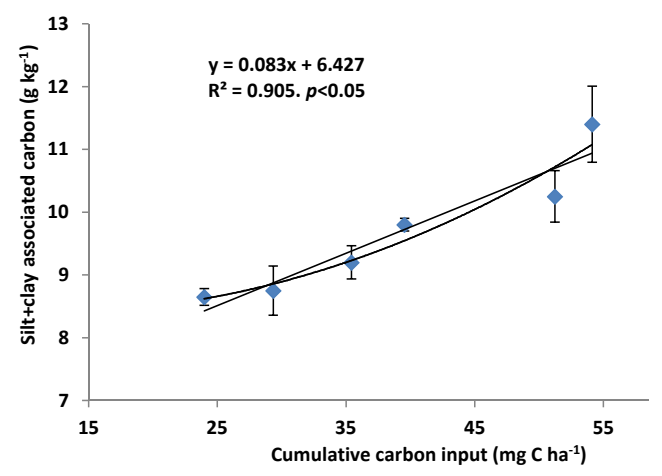

Figure 1. Relation between cumulative carbon input and silt+clay associated carbon (error bars represent the standard error of mean).

\subsection{Effect of levels of fertilizers on organic C content in soils and its allocation into different pools}

There was an increase in the amount of carbon sequestrated in soils with the increasing levels fertilizer from control to $150 \%$ NPK. However, the relation between fertilizer levels and amount of carbon sequestrated followed a sigmoid curve. Amount of carbon sequestrated increased rapidly or linearly with increased fertilizer levels up to $100 \%$ NPK, and then the degree of increase in the amount of carbon sequestrated decreased (Figure 2).

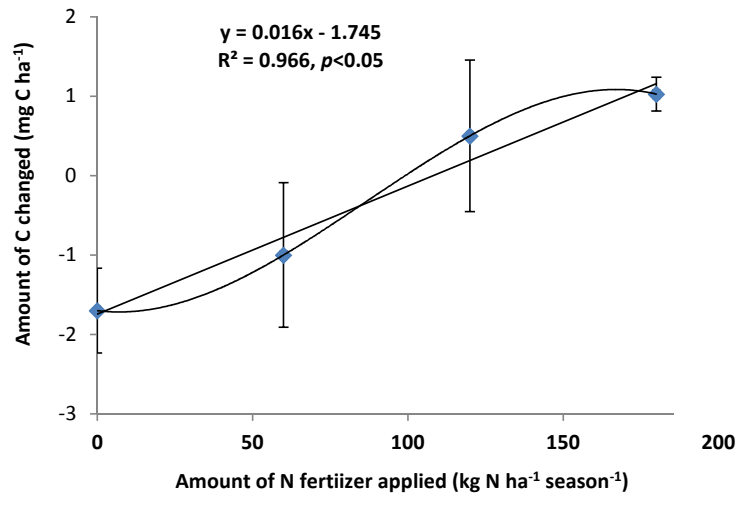

Figure 2. Relation between amounts of carbon change with $\mathrm{N}$ fertilizer applied (error bars represent the standard error of mean).

There was an increase in the allocation of sequestrated carbon into passive pools (LL and NL) with an increase in fertilizer quantity up to $100 \%$ NPK, then it decreased with $150 \%$ NPK. An increase in N inputs over the recommended dose (100\% NPK) possibly made the plants more succulent (i.e. reduced lignin ${ }^{65}$ and cellulose contents in plant tissue) resulting in an ease in their decomposition and enhancement in microbial biomass or active pool of $\mathrm{C}$ in soil with a concomitant drop in percent distribution (of TOC) into passive pools.

Application of different levels of fertilizers also influenced allocation of $\mathrm{C}$ into different pools, besides TOC and OC. Excepting fraction 2 (labile pool), all the pools of $\mathrm{C}$ estimated with a gradient of oxidizing conditions recorded an increase with fertilization compared with the control treatment. Increasing levels of fertilizer (inorganic $\mathrm{N}$ inputs) could induce a positive priming effect resulting in a net loss of soil C (Russel et al., 2005), especially when crop residue was not returned to the soil. In our case the reduction was observed in the amount of labile pools. 


\subsection{Sensitivity index}

The sensitivity index helps to identify the $\mathrm{C}$ fractions which are more responsive to management practices. The results indicated that MBC (31.2-129.7\%) and $\mathrm{KMnO}_{4}(12.4-92.8 \%)$ fractions were the most sensitive ones as compared to OC, silt+clay associated and POC fractions estimated through Walkley and Black (1934), and dry combustion (CHNS analyser) methods with sensitivity index values ranging between 2.5-33.4, 1.2-31.8 and 17.6-85.9\%, respectively (Table 3 ). The C pool with higher sensitivity index could be an early indicator with respect to changes in $\mathrm{C}$ status of soil due to management practices. In this study under double rice cropping system in Inceptisols, MBC is the most sensitive indicator of soil carbon dynamics and quality. The superiority of POC over the SOC as a good sensitive indicator was also reported by Yan et al. (2007).

\subsection{Carbon management index}

Carbon management index (CMI) is an important tool to compare and evaluate the efficiency of different management practices or soil productivity. It accounts for the changes in both labile and total $\mathrm{C}$; and could be a better indicator of sensitivity of SOC to management practices. Higher CMI values indicate that the management practices are sustainable to maintain SOC. In the present study sole organic and in combination with inorganic application showed higher CMI values than sole inorganic treatments. These higher values might be due to application of external $\mathrm{C}$ inputs to soil and these practices could maintain stable SOC than other systems (Chaudhary et al., 2017).

In the present study FYM and 100\% NPK+FYM treatments had higher CMI (Table 5) indicating greater stable SOC. This was corroborated by the presence of higher $\mathrm{C}$ in passive pool under the treatments. Improved CMI values under integrated nutrient management system also reported by Moharana et al. (2012). From these results we could conclude that the application of organics had a higher rehabilitation rate.

Table 5. Benefit: cost ratio, partial factor productivity and cost of carbon sequestration under different management practices in double rice cropping system

\begin{tabular}{lcccccccrr}
\hline Treatment & $\begin{array}{l}\text { Grain yield } \\
\left(\mathrm{mg} \mathrm{ha}^{-1}\right)\end{array}$ & $\begin{array}{l}\text { Cost of } \\
\text { cultivation } \\
1000 \mathrm{ha}^{-1}\end{array}$ & $\begin{array}{l}\text { Returns } \\
1000 \mathrm{ha}^{-1}\end{array}$ & $\begin{array}{l}\text { Net returns } \\
1000 \mathrm{ha}^{-1}\end{array}$ & B:C ratio & PFP & $\mathrm{kg}^{-1} \mathrm{C}$ & CMI & SYI \\
\hline Control & 81 & 398 & 1140 & 741 & 1.9 & - & - & - & 0.61 \\
\hline $50 \%$ NPK & 121 & 471 & 1691 & 1220 & 2.6 & 23.4 & - & 118 & 0.61 \\
\hline $100 \%$ NPK & 146 & 543 & 2049 & 1506 & 2.8 & 14.1 & 906 & 123 & 0.68 \\
\hline $150 \%$ NPK & 161 & 616 & 2250 & 1634 & 2.7 & 10.4 & 600 & 133 & 0.68 \\
\hline $100 \%$ NPK+FYM & 155 & 683 & 2163 & 1479 & 2.2 & 7.6 & 204 & 157 & 0.70 \\
\hline FYM & 109 & 678 & 1532 & 854 & 1.3 & 5.5 & 81 & 194 & 0.63 \\
\hline
\end{tabular}

$\mathrm{CMI}=$ Carbon management index, $\mathrm{SYI}=$ Sustainable yield index, $\mathrm{PFP}=$ Partial factor productivity, $\mathrm{B}: \mathrm{C}=$ benefit: cost ratio. 


\subsection{Carbon sequestration, stabilization and critical carbon input:}

The amount and rate of carbon sequestration were significantly increased in the treatments with application of organics alone and in combination with inorganic fertilizer. This was due to increased amount of plant residue $\left(0.17,1.21\right.$ and $1.30 \mathrm{Mg} \mathrm{C}^{-1} \mathrm{y}^{-1}$ through stubble biomass, root biomass and rhizodeposition, respectively) $\mathrm{C}$ left over in soil $(2.68 \mathrm{Mg} \mathrm{C}$ $\mathrm{ha}^{-1}$ ) owing to increased yield, external application of $\mathrm{C}$ through FYM (0.98 $\mathrm{Mg} \mathrm{C}^{-1}$ ) and interaction between NPK and organics (Majumder et al. 2008) in integrated treatment. On the other hand, in sole FYM treatment it was due to a large amount of external carbon addition (1.96 $\left.\mathrm{Mg} \mathrm{C} \mathrm{ha}^{-1}\right)$ and increased amount of plant residue (1.91 $\left.\mathrm{Mg} \mathrm{C} \mathrm{ha}^{-1}\right)$. This was evident from the significant positive correlation $(\mathrm{r}=0.84$, $\mathrm{p}<0.05$ ) between annual $\mathrm{C}$ inputs and TOC. The slope of the linear regression (carbon sequestration efficiency, CSE) between the SOC sequestration rate and gross carbon inputs was 28.4, which indicated that $28.4 \%$ of C input per year was sequestrated as SOC.

Results showed that only $28.9 \%$ of applied FYM was stabilized in soil allowing $71.1 \%$ to go out of the system. Contrarily, Majumder et al. (2008) and Mandal et al. (2008) showed a higher amount of carbon stabilization (73 and $67.8 \%$ of applied FYM, respectively) in soils while working with rice-based cropping system in Inceptisol in eastern part of India. Such lower carbon stabilization in our study may be due to strong oxidative forces of the high temperature (temperature goes upto $47-48{ }^{\circ} \mathrm{C}$ during peak summer) prevailing in this region during summer, when the soils remain fallow.

A significant positive linear relationship between the changes in SOC and the total cumulative crop residue $\mathrm{C}$ inputs to the soil over 14 years ( $\mathrm{Y}=0.284 \mathrm{x}-9.308$; $\mathrm{R}^{2}=0.84, p<0.05$ ) was observed (Figure 3). Many researchers (Mandal et al., 2007; Srinivasarao et al., 2012b) also observed similar relationship. The figure depicted a strong linear relationship indicating that even after 14 years of $\mathrm{C}$ addition through FYM and crop residues, the soils had still capacity to store $\mathrm{C}$ and had potential for further sequestration. The slope of the curve represented the rate of conversion of input $\mathrm{C}$ to SOC, which is about $28.4 \%$ of each additional $\mathrm{Mg}$ $\mathrm{C}$ input per hectare under the tested cropping system. The results also revealed that in order to maintain the existing SOC level (zero change) for long-term sustenance of the production system, a critical amount of $2.34 \mathrm{MgC} \mathrm{ha}{ }^{-1} \mathrm{y}^{-1}$ has to be incorporated into the soil (Figure 3).

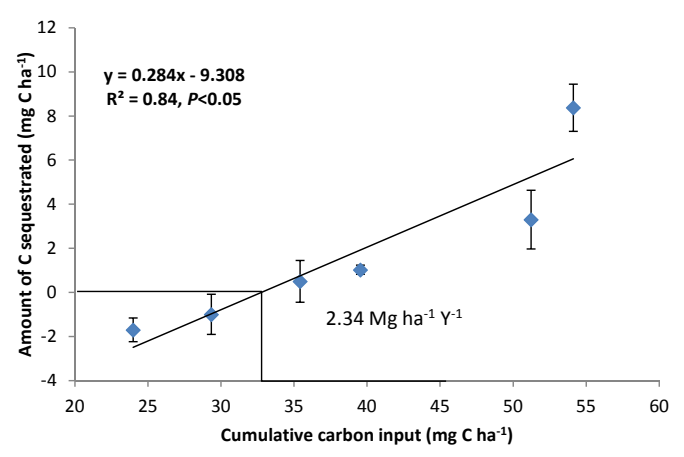

Figure 3. Relationship between cumulative $\mathrm{C}$ input and $\mathrm{C}$ sequestration and critical $\mathrm{C}$ input value for zero change in soil organic carbon (SOC) stock (error bars represent the standard error of mean).

\subsection{Economics of yields and $C$ sequestration}

Results of calculation of benefit: cost ratio (B:C) for different treatments showed that $100 \%$ NPK treatment helped to get more profits over the other treatments tested. The B:C ratio increased with increasing dose of fertilization upto $100 \%$ NPK, then decreased with 150\% NPK (Table 5). In 150\% NPK treatment yield was increased but the cost of inputs 
were higher than the increased yield price, hence B: $\mathrm{C}$ ratio declined. Treatments with organics i.e. $100 \%$ NPK+FYM and FYM showed lower B: C ratio $(2.2$ and 1.3 , respectively), as the cost of organic inputs (FYM) was higher.

The cost of carbon sequestration in soils under agricultural land uses is the function of cropping system, intensity and management practices. Among the treatments compared FYM treated soils showed lower cost for sequestering unit carbon $\left(81 \mathrm{~kg}^{-1} \mathrm{C}\right)$ followed by $100 \%$ NPK+FYM $\left(204 \mathrm{~kg}^{-1} \mathrm{C}\right), 150 \%$ NPK $\left(600 \mathrm{~kg}^{-1}\right.$ C) and $100 \%$ NPK $\left(906 \mathrm{~kg}^{-1} \mathrm{C}\right)$.

Results indicates that $100 \%$ NPK treatment can bring more profits to the farmers but failed to maintain soil sustainability, on the other hand FYM applied treatment can fix more $\mathrm{C}$ and have greater potential to maintain soil sustainability and quality but failed to bring good profits. But integrated treatment $100 \%$ NPK+FYM can capable of generating more profits besides maintaining soil sustainability. This was also supported by higher SYI in NPK+FYM treatment.

\subsection{Relationship among SOC pools, C sequestration and SYI}

Carbon sequestration had significant $(p<0.01)$ positive correlation with very labile $\mathrm{C}(\mathrm{r}=0.71)$, non labile C $(r=0.80)$, MBC $(r=0.84)$, POC $(r=0.87)$, Pox$\mathrm{C}(\mathrm{r}=0.83)$ and silt+clay associated $\mathrm{C}(\mathrm{r}=0.89)$. Our findings were in line with Datta et al. (2015) who also observed significant positive correlations among the SOC pools under different land uses in semiarid North West India. The SYI had significant $(p<0.01)$ positive correlations with labile and non labile $\mathrm{C}$ pools $(\mathrm{r}=0.51, p<0.05)$ and cumulative $\mathrm{C}$ input values $(\mathrm{r}=0.51, p<0.05)$. Organic matter in soil acts as a storehouse of nutrients. Higher $\mathrm{C}$ inputs helped in enhancing organic matter content in soil which, in turn, supplied nutrient elements to plants and thereby improved crop yield and justified the existence of significant positive correlations among SOC pools, C inputs and SYI.

\section{Conclusion}

Double rice cropping system even under hot semi-arid climate with balanced and integrated (with FYM) nutrient management caused an increase in SOC. However, a higher part (71\%) of the applied C was lost leaving a lower amount (29\%) to stabilize into soil. To counteract the loss and maintain the SOC under such climate a minimum of $2.34 \mathrm{Mg} \mathrm{Cha}^{-1} \mathrm{y}^{-1}$ need to be incorporated into soil. Nutrient management with organic maintained a good amount of $\mathrm{C}$ in microbial biomass, and other labile pools besides a higher value of carbon management index and sensitivity index. Management practices with $100 \%$ NPK+FYM showed a greater crop yield sustainability with lower cost of carbon sequestration. Double rice system with balance fertilization ( $100 \% \mathrm{NPK}+\mathrm{FYM})$ thus not only helped to sustain the crop yield but also health of soils under hot semi-arid climatic conditions.

\section{Acknowledgements}

We are grateful to Dr. K. Raja Reddy, former Director of Research, Acharya N.G. Ranga Agricultural University, Hyderabad, for allowing us to use the longterm experiment and providing basic initial soil data for our study.

\section{References}

Allison, L.E., Moodie, C.D. 1965. Carbonate. In C.A. Black et al. (eds.) Methods of soil analysis. Part 2.2 nd ed. Agron.Monogr. 9. ASA, CSSA, and SSSA, Madison, WI. pp. 1379-1400. 
Basak, N., Datta, A., Mitran, T., Singha Roy, S., Saha, B. N., Biswas, S., Mandal, B. 2016. Assessing soil quality indices for sub-tropical rice-based cropping systems in India. Soil Res. 54, 20-29.

Benbi, D.K., Brar, J.S. 2009. A 25-year record of carbon sequestration and soil properties in intensive agriculture. Agron. Sustain. Dev. 29, 257-265.

Bharali, A., Baruaha, K.K., Bhattacharyya, P., Gorha, D. 2017. Integrated nutrient management in wheat grown in a northeast India soil: Impacts on soil organic carbon fractions in relation to grain yield. Soil Tillage Res. 168, 81-91.

Blair, G.J., Lefroy, R.D.B., Lisle, L. 1995. Soil carbon fractions, based on their degree of oxidation and the development of a carbon management index for agricultural systems. Aust. J. Agric. Res. 46, 1459-1466.

Blake, G.R., Hartge, K.H. 1986. Bulk density. In: Klute, A., et al. (Ed.), Methods of Soil Analysis. Part 1. Physical and Mineralogical Methods. Agron. Monogr. 9. ASA and SSSA, Madison, WI, pp: 363-375

Bronson, K.F., Cassman, K.G., Wassmann, R., Olk, D.C., Noordwijk, M., van Garrity, D.P. 1998. Soil carbon dynamics in different cropping systems in principal ecoregions of Asia. In: Manage- ment of Carbon Sequestration in Soil (eds Lal R, Kimble JM, Follett RF, Stewart BA), pp. 35-57. CRC Press, Boca Raton, NY.

Cambardella, C.A., Elliott, E.T. 1992. Particulate soil organic matter changes across a grassland cultivation sequence. Soil Sci. Soc. Am. J. 56, 777-783.

Chan, K.Y., Bowman, A., Oates, A. 2001. Oxidizable organic carbon fractions and soil quality changes in an oxic paleustaff under different pastures leys. Soil Sci. 166, 61-67.

Chaudhary, S., Dheri, G.S., Brar, B.S. 2017. Longterm effects of NPK fertilizers and organic manures on carbon stabilization and management index under rice-wheat cropping system. Soil Tillage Res. 166, 59-66.

Costanza, R., de Groot, R., Sutton, P., van der Ploeg, S., Anderson, S., Kubiszewski, I., Farber, S., Turner., R. 2014. Changes in the global value of ecosystem services. Global Environmental ChangeHuman and Policy Dimensions 26, 152-158.

Datta, A., Basak, N., Chaudhari, S.K., Sharma, D.K. 2015. Soil properties and organic carbon distribution under different land uses in reclaimed sodic soils of North-West India. Geoderma Reg. 4, 134-146.

Feng, W., Xu, M., Fan, M., Malhi, S.S., Schoenau, J.J., Six, J., Plante, A.F. 2014. Testing for soil carbon saturation behavior in agricultural soils receiving long-term manure amendments. Can. J. Soil Sci. 94, 281-294.

Ghosh, S., Wilson, B.R., Mandal, B., Ghoshal, S.K., Growns, I. 2010. Changes in soil organic carbon pool in three long-term fertility experiments with different cropping systems and inorganic and organic soil amendments in the eastern cereal belt of India Aust. J. Soil Res. 48, 413-420.

Hassink, J., 1995. Density fractions of soil macro-organic matter and microbial biomass as predictors of $\mathrm{C}$ and $\mathrm{N}$ mineralization. Soil Biol. Biochem. 27, 1099-1108.

Ladha, J.K., Dawe, D., Pathak, H., Padre, A.T., Yadav, R.L., Singh, B., Singh, Y., Singh, Y., Singh, P., Kundu, A.L., Sakal, R., Ram, N., Regmi, A.P., Gami, S.K., Bhandari, A.L., Amin, R., Yadav, C.R., Bhattarai, E.M., Das, S., Aggarwal, H.P. Gupta, R.K., Hobbs, P.R. 2003. How extensive are yield declines in long-term rice-wheat experiments in Asia? Field Crops Res. 81, 159-180.

Lal, 2014. Societal value of soil carbon. J. Soil Water Con. 69(6), 186A-192A.

Lal, R. 2004. Soil carbon sequestration in India. Climatic Change. 65, 277-296. 
Lal, R. 2009. Soil carbon sequestration for climate change mitigation and food security. Souvenir, Platinum Jubilee Symposium on Soil Science in Meeting the Challenges to Food Security and Environmental Quality. Indian Society of Soil Science, New Delhi, India. pp. 39-46.

Lal, R. 2011. Sequestering carbon in soils of agroecosystems. Food Policy 36, S33-S39.

Majumder, B., Mandal, B., Bandyopadhyay, P.K., Chaudhury, J. 2007. Soil organic carbon pools and productivity relationships for a 34 year old rice-wheat-jute agroecosystem under different fertilizer treatments. Plant Soil. 297, 53-67.

Majumder, B., Mandal, B., Bandyopadhyay, P.K., Gangopadhyay, A., Mani, P.K., Kundu, A.L., Majumder, D. 2008. Organic amendments influence soil organic carbon pools and crop productivity in 19 year old rice-wheat agroecosystems. Soil Sci. Soc. Am. J. 72, 775-785.

Mandal, B., Majumder, B., Adhya, T.K., Bandyopadhyay, P.K., Gangopadhyay, A., Sarkar, D., Kundu, M.C., Gupta Choudhury, S., Hazra, G.C., Kundu, S., Samantaray, R.N., Misra, A.K. 2008. Potential of double-cropped rice ecology to conserve organic carbon under subtropical climate. Glob. Chang. Biol. 14, 2139-2151.

Mandal, B., Majumder, B., Bandyopadhyay, P.K., Hazra, G.C., Gangopadhyay, A., Samantaray, R.N., Misra, A.K., Chaudhury, J., Saha, M.N., Kundu, S. 2007. The potential of cropping systems and soil amendments for carbon sequestration in soils under long-term experiments in subtropical India. Glob. Chang. Biol. 13, 357-369.

Moharana, P.C., Sharma, B.M., Biswas, D.R., Dwivedi, B.S., Singh, R.V. 2012. Long term effect of nutrient management on soil fertility and soil organic carbon pools under a 6-year-old pearl millet-wheat cropping system in an Inceptisol of subtropical India. Field Crop Res. 136, 32-41.
Muñoz, C., Cruz, B., Rojo, F., Campos, J., Casanova, M., Doetterl, S., Bockx, P., Zagal, E. 2016. Temperature sensitivity of carbon decomposition in soil aggregates along a climatic gradient. J. Soil Sci. Plant Nutr. 16, 461-476.

Nelson, D.W., Sommers, L.E. 1982. Total carbon, organic carbon, and organic matter. In: Methods of Soil Analysis. Part 2, 2nd edn (eds Page AL, Miller RH, Keeney DR), pp. 101-129. Agronomy Monograph No 9, American Society of Agronomy, Madison, Wisconsin.

Pathak, H., Byjesh, K., Chakrabarti, B., Aggarwal, P.K. 2011. Potential and cost of carbon sequestration in Indian agriculture: Estimates from longterm field experiments. Field Crops Res. 120, 102-111.

Puget, P., Drinkwater, L.E. 2001. Short-term dynamics of root and shoot derived carbon from a leguminous green manure. Soil Sci. Soc. Am. J. 65, 771-779.

Purakayastha, T.J., Rudrappa, L., Singh, D., Swarup, A., Bhadraray, S. 2008. Long- term impact of fertilizers on soil organic carbon pools and sequestration rates in maize-wheat-cowpea cropping system. Geoderma. 144, 370-378.

Russell, A.E., Laird, D.A., Parkin, T.B., Mallarino, A.P. 2005. Impact of nitrogen fertilization and cropping system on carbon sequestration in Midwestern Mollisols. Soil Sci. Soc. Am. J. 69, 413-422.

Saito, M., Watanabe, I. 1978. Organic matter production in rice field floodwater. Soil Sci. Plant Nutr. 24, 427-440.

Schuman, G.E., Janzen, H.H., Herrick, J.E. 2002. Soil carbon dynamics and potential carbon sequestration by rangelands. Environ. Pollut. 116, 391-396.

Sharma, K.L., Mandal, U.K., Srinivas, K., Vittal, K.P.R., Mandal, B., Grace, J.K., Ramesh, V. 2005. Long-term soil management effects on crop yields 
and soil quality in a dryland Alfisol. Soil Tillage Res. 83, 246-259.

Six, J., Conant, R.T., Paul, E.A. 2002. Stabilization mechanisms of soil organic matter: implications for C-saturation of soils. Plant Soil. 241, 155-176.

Srinivasarao, Ch., Venkateswarlu, B., Lal, R., Singh, A. K., Vittal, K.P. R., Kundu, S. 2012a. Long-term effects of soil fertility management on carbon sequestration in a rice-lentil cropping system of the Indo-Gangetic plains. Soil Sci. Soc. Am. J. 76, 168-178.

Srinivasarao, Ch., Venkateswarlu, B., Lal, R., Singh, A.K., Kundu, S., Vittal, K.P.R., Balaguravaiah, G., Vijaya Shankar Babu, M., Ravindra Charya, G., Prasadbabu, M.B.B., Reddy, T.Y. 2012b. Soil carbon sequestration and agronomic productivity of an Alfisol for a groundnut-based system in a semiarid environment in southern India. Europ. J. Agronomy. 43, 40- 48.

Srinivasarao, Ch., Venkateswarlu, B., Lal, R., Singh, A.K., Kundu, S., Vittal, K.P.R., Patel, J.J., Patel, M.M. 2014. Long-term manuring and fertilizer effects on depletion of soil organic carbon stocks under pearl millet-cluster bean-castor rotation in western India. Land Degrad. Dev. 25, 173-183.

Stewart, C.E., Paustian, K., Conant, R.T., Plante, A.F., Six, J. 2007. Soil carbon saturation: concept, evidence and evaluation. Biogeochemistry. 86, 1931.

Swarup, A. 1998. Emerging soil fertility management issues for sustainable crop productivity in irrigated systems, in Swarup, A., Reddy, D.D. and Prasad, R.N. (eds.), Long-term soil fertility management through integrated plant nutrient supply, Indian Inst. Soil. Sci., Bhopal, India, 54-98.
Tian, F., Zhang, Z., Chang, X., Wei, X., Wu, G. 2016. Effects of biotic and abiotic factors on soil organic carbon in semi-arid grassland. J. Soil Sci. Plant Nutr. 16, 1087-1097.

Tian, K., Zhao, Y., Xu, X., Hai, N., Huang, B., Deng, W. 2015. Effects of long-term fertilization and residue management on soil organic carbon changes in paddy soils of China: a meta-analysis. Agric. Ecosyst. Environ. 204, 40-50.

Timsina, J., Mangi, L., Jat, L., Majumdar, K. 2010. Rice-maize systems of South Asia: current status, future prospects and research priorities for nutrient management. Plant Soil. 335, 65-82.

Vance, E.D., Brookes, P.C., Jenkinson, D.S. 1987. An extraction method for measuring soil microbial biomass C. Soil Biol. Biochem. 19, 703-707.

Voroney, R.P., Paul, E.A. 1984. Determination of KC and $\mathrm{KN}$ in situ for calibration of the chloroform fumigation-incubation method. Soil Biol. Biochem. 16, 9-14.

Walkley, A., Black. I.A. 1934. An examination of the Degtjareff method for determining soil organic matter and a proposed modification of the chromic acid titration method. Soil Sci. 37, 29-38.

Wright, A.L., Hons, F.M. 2005. Tillage impacts on soil aggregation and carbon and nitrogen sequestration under wheat cropping sequences. Soil Tillage Res. 84, 67-75.

Yan, D.Z., Wang, D.J., Yang, L.Z. 2007. Long-term effect of chemical fertilizer, straw, and manure on labile organic matter fractions in a paddy soil. Biol. Fertil. Soils. 44, 93-101.

Zang, H., Wangb, J., Kuzyakova, Y. 2016. N fertilization decreases soil organic matter decomposition in the rhizosphere. Appl. Soil Ecol. 108, 47-53. 